\title{
THE GROWTH OF LOCAL TREE SPECIES ON POST-COAL MINING AREAS IN EAST KALIMANTAN
}

\author{
Burhanuddin Adman*, Ardiyanto W. Nugroho, and Ishak Yassir \\ Research and Development Institute for Natural Resources Conservation Technology \\ Jl. Soekarno Hatta Km. 38 Samboja PO Box 578 Balikpapan76112, Indonesia
}

Received: 2 June 2020, Revised: 1 October 2020, Accepted: 1 October 2020

THE GROWTH OF LOCAL TREE SPECIES ON POST-COAL MINING AREAS IN EAST KALIMANTAN. Post-coal mining areas need rehabilitation to restore its functionality. Not all plants could grow well on bare ex-coal mining area because of the excessive light intensity and extreme temperature fluctuations. This study is aimed to determine suitable local tree species for rehabilitating mined areas. Planting was carried out in November 2012, and observations were made in November 2015. The study site was in the district of Samboja, Kutai Kartanegara, East Kalimantan Province, Indonesia. Research results revealed that seven tree species survived well in the ex-coal mining land, i.e., Vitex pinnata L., Sysygium scortechinii (Merr.) Merr. \& Perry, Sysygium polyantbum (Wight) Walp., Shorea balangeran (Korth.) Burck, Macaranga motleyana (Mull.Arg.) Mull.Arg., Cleistanthus myrianthus (Hassk.) Kurz and Sysygium lineatum (DC.) Merr. \& L.M. Perry. From the seven species V. pinnata, S. scortechinii and S. polyanthum performed best in both survival and growth rates. This study suggests those three species are excellent local tree species for ex-coal mining rehabilitation, not only because of their high survival rate $(\geq 80 \%)$ and fast-growing but also they produce favourable fruits and flowers for wildlife.

Keywords: Rehabilitation, local tree species, post-coal mining area

PERTUMBUHAN BEBERAPA JENIS POHON LOKAL DI LAHAN PASCA TAMBANG BATU BARA DI KALIMANTAN TIMUR. Daerah bekas tambang batu bara perlu rehabilitasi untuk mengembalikan fungsinya. Namun, tidak semua jenis tanaman dapat tumbub dengan baik di laban bekas tambang batu bara, karena kawasan yang terbuka menjadikan intensitas cabaya matahari berlebihan dan fuktuasi subu yang ekstrim. Penelitian ini bertujuan untuk menentukan jenis pohon lokal yang cocok untuk merehabilitasi areal bekas tambang. Penanaman dilakukan pada bulan November 2012, dan observasi dilakukan pada bulan November 2015. Lokasi penelitian berada di Kabupaten Samboja, Kutai Kartanegara, Provinsi Kalimantan Timur. Hasil penelitian menunjukkan bahwa terdapat tujuh jenis pohon yang mampu bertahan bidup dengan baik di lahan bekas tambang batubara, yaitu Vitex pinnata L., Syzygium scortechinii (Merr.) Merr. \& Perry, Syzygium polyanthum (Wight) Walp., Shorea balangeran (Korth.) Burck, Macaranga motleyana (Mull.Arg.) Mull.Arg., Cleistanthus myrianthus (Hassk.) Kurz. dan Syzygium

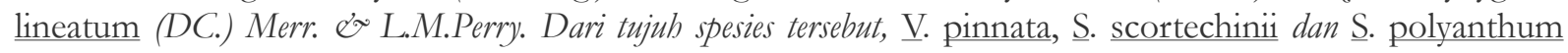
tercatat memiliki pertumbuhan terbaik dan mampu bertahan dalam lahan terbuka. Studi ini menunjukkan babwa ketiga spesies tersebut adalah spesies pohon lokal yang disarankan untuk. merehabilitasi tambang batu bara, tidak hanya karena tingkat bidupnya tinggi $(\geq 80 \%)$ dan cepat tumbuh, namun juga menghasilkan buah dan bunga yang menguntungkan bagi satwa liar.

Kata kunci: Rehabilitasi, jenis pohon lokal, area pasca tambang batu bara

*Corresponding author: burhanuddinadman@gmail.com 


\section{INTRODUCTION}

In the National Energy Conservation Master Plan, it is mentioned that coal is promoted to be one of the primary energy sources in Indonesia by 2020 including East Kalimantan Province (Kusmana, Setiadi, \& Al-Anshary, 2013). Coal is one of the primary energy sources to generate electricity, which is essential to support economic growth for East Kalimantan and also for the whole country. The contribution of mining and quarrying sector to the economy in this province is estimated to increase from $36.2 \%$ to $50.5 \%$ from 2001 to 2011(Ishak, 2013). However, coal mining has resulted in negative environmental impacts such as loss of biodiversity (Pandey, Agrawal, \& Singh, 2014), degradation of the watershed quality and quantity (Merem et al., 2014; Zegre, Miller, Maxwell, \& Lamont, 2014), as well as toxicity in the aquatic environment (Turner et al., 2013). Therefore, sustainable coal mining practices in East Kalimantan need to be promoted by reducing its negative impacts on the environment.

Reclamation and rehabilitation of postcoal mining areas need to be conducted to reduce the negative impacts of coal mining activities on the environment. These activities ensure ecosystem services to recover to the previous functions, which are essential to support human well-being and prevent further negative impacts on the ground (Yassir, 2013). Furthermore, based on the national regulation Act No 4/ 2009 about Mineral and Coal Mining in Indonesia, rehabilitation and reclamation after coal extractions are an obligation for the mining concession holders in this country. Therefore, reclamation and restoration are an essential activity to support sustainable mining in Indonesia (Mansur, 2010).

In the coal mining area rehabilitation projects, the use of local tree species in the species selection is one of the key factors to the success of the project. The local tree species have several advantages, such as more adaptive to the environment, maintaining the genetic integrity of the population of local species, preventing the invasion of exotic or non-local species (Gray, 2002). Besides, these local plant species could also contribute to the conservation programs. Unlike exotic plant species, the use of local plant species has minimum impacts in altering the species composition and structure of the landscape from the previous state before mining activities were conducted. On the other hand, the use of exotic plant species has some negative impacts on the environment and conservation programs (Radiansyah et al., 2015).

The success of revegetation can be evaluated by determining the plant's growth performance (Istomo, Setiadi, \& Putri, 2013). Growth performance, which can be described as plant's height, diameter and survival rate, is an important aspect to observe in this study because it can be the indicators for plant species evaluation in adapting to a new environment. Environmental conditions in the post-coal mining area are different compared to the native habitat of the ten local plant species in this study. A study conducted by Villacís, Casanoves, Hang, Keesstra, and Armas (2016) by measuring height, tree diameter, and survival rate as growth parameter for 20 plant species in the rehabilitation of post-oil mining areas in Amazon Basin. That study aimed to provide a list of plant species suitable for post-oil mining rehabilitation. Meanwhile, a study conducted by Todd, Rufaut, Craw, and Begbie (2009) used plant survival and plant height growth in an opencast coal mining rehabilitation using indigenous plant species in New Zealand. Besides, Mushia, Ramoelo, and Ayisi (2016) used plant height, plant cover and plant biomass as growth indicators in a study determining the impacts of coal mine stockpile quality on plant growth and productivity.

In 2012, a rehabilitation project of the postcoal mining area had been conducted by planting ten local tree species in East Kalimantan, Indonesia (Adman \& Yassir, 2016). The study reported that three tree species had a survival rate of more than $90 \%$ at the age of one year, indicating that they can grow well on post-coal mining areas. Those species are Vitex pinnata L., Syzygium scortechinii (King) P. Chanaranothai \& J. Parnell, Kew, Syzygium polyanthum (Wight) 
Walp. It is also reported that although they had a low survival rate, Bridelia glanca Blume and Ficus variegata Blume, could again grow well on post-coal mining land during the first year. According to a study, the critical period occurred between one to two years after planting for plant establishment in the tropical areas (Villacís et al., 2016). Therefore, this study aimed to evaluate the further performance of the ten local tree species planted in post-coal mining areas in East Kalimantan. This paper reported the growth performance of the ten local tree species in the post-coal mining area at the age of 4 years. It is crucial to provide alternative local plant species that are suitable to the local environment, which is also essential for conservation programs rather than exotic species.

\section{MATERIAL AND METHOD}

\section{A. Study Site and Materials}

The study area was a post-coal mining land at S01'00'44.1" E116 54'27.2", located in the district of Samboja, Kutai Kartanegara, East Kalimantan Province, Indonesia. The study was carried out in November 2012 by planting ten local tree species in one of the company's postmining areas. The selection of the ten species
(Tabel 1) was based on recommendations of the study reported by Yassir and Omon (2009).

\section{B. Methods}

Seedlings (wildlings) of the ten local plant species were collected from the forests located around the mining areas. After collection, the seedlings were transported and maintained in the nursery under 50\% shading. Pot size used was $10 \times 15 \mathrm{~cm}$ filled with a mixture of topsoil and compost with a ratio of $1: 1(\mathrm{v} / \mathrm{v})$. During the first three months, seedlings were kept under a lid. The lid was used to keep the humidity high $(>80 \%)$. Watering inside the lid was done at humidity less than $80 \%$. After the seedlings produced new shoots, the lid was opened gradually starting from $10 \%$ opening for the $1^{\text {st }}$ week, then $25 \%$ at the following week, then $50 \%, 75 \%$ to $100 \%$ opening, respectively with a one-week interval. After the lid opened 100\%, the seedlings were kept in the nursery until they were ready for planting ( \pm 5-7 months). Watering in the nursery was done twice a day, if it did not rain, to maintain humidity, and it was reduced if it is raining.

The seedlings were also sorted to obtain a uniform size in diameter and height before planting. Meanwhile, the planting area was covered by topsoil with $\pm 50 \mathrm{~cm}$ thickness based

Table 1. The botanical name of local plant species planted in this study

\begin{tabular}{|c|c|c|c|c|}
\hline No & Botanical name & Family & Local name & Uses \\
\hline 1. & Vitex pinnata L. & Lamiaceae & Laban & $\begin{array}{l}\text { Wood construction, } \\
\text { firewood, medicinal plant }\end{array}$ \\
\hline 2. & Sysygium polyanthum (Wight) Walp & Myrtaceae & Salam & $\begin{array}{l}\text { Flavouring spices, medicinal } \\
\text { plant }\end{array}$ \\
\hline 3. & Cleistanthus myrianthus (Hassk.) Kurz & Phyllanthaceae & Jari-jari & - \\
\hline 4. & Sysygium lineatum (Blume) Merr. \& Perry & Myrtaceae & Gelam tikus & $\begin{array}{l}\text { Wood construction, } \\
\text { medicinal plant, fruits edible }\end{array}$ \\
\hline 5. & Sysygium scortechinii (Merr.) Merr. \& Perry & Myrtaceae & Obah air & Fruits edible \\
\hline 6. & Bridelia glauca Blume & Phyllanthaceae & Kanidei & $\begin{array}{l}\text { Wood construction, fruits } \\
\text { edible }\end{array}$ \\
\hline 7. & Ficus variegata Blume & Moraceae & Nyawai & $\begin{array}{l}\text { Wood construction, fruits } \\
\text { edible }\end{array}$ \\
\hline 8. & Schima wallichii (DC) Korth. & Theaceae & Puspa & $\begin{array}{l}\text { Plywood, pulp for paper, } \\
\text { medicinal plant }\end{array}$ \\
\hline 9. & $\begin{array}{l}\text { Macaranga motleyana (Müll. Arg.) Müll. } \\
\text { Arg. }\end{array}$ & Euphorbiaceae & Mahang & - \\
\hline 10. & Shorea balangeran (Korth.) Burck & Dipterocarpaceae & Kahoi & Wood construction. \\
\hline
\end{tabular}



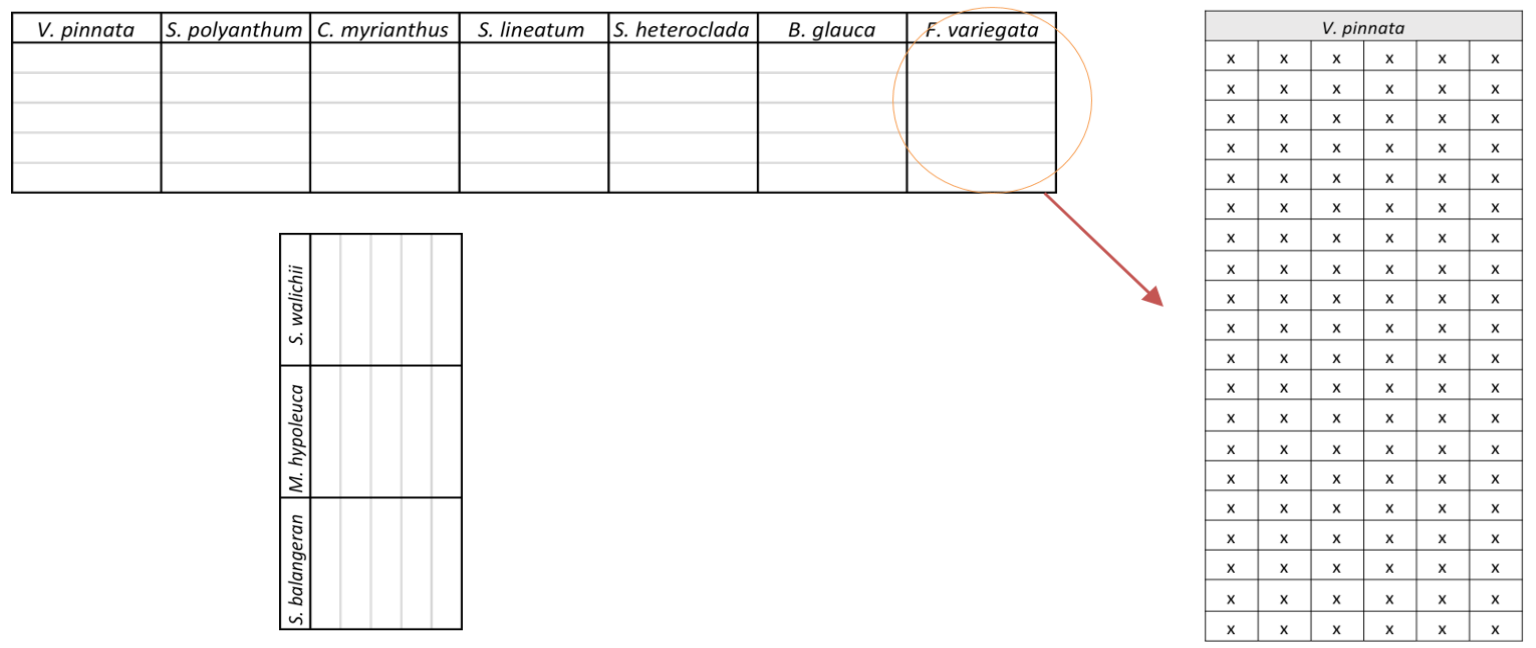

Figure 1. Planting layout and research design

on the company's standard operating procedure before planting. The size of the planting holes was $30 \mathrm{~cm}$ in length, width and depth. Each of the planting holes was filled with $\pm 1 \mathrm{~kg}$ compost and mixed with the soil for fertilization of the plants. The compost was made from decomposed remains of plants. The compost was applied once before planting. Each plant species was planted in six lines, consisting of 20 plants in each line, with $3 \mathrm{~m} \times 3 \mathrm{~m}$ spacing (Figure 1). Therefore, 1200 plants were planted in the area, and the dead plants were not replanted. This layout was implemented due to the availability of the post-coal mining area in the company. After planting, weeding was also regularly conducted four times a year to eliminate weeds and providing growing space for the plants. Planting holes, compost dosage and plant spacing, were based on standard operating procedures applied by PT. Singlurus Pratama.

Observations on the growth of the ten local plant species were regularly conducted every six months up to the age of four year. Data collection included plants' survival rates, heights and diameters at planting and after four years after planting and soil chemical characteristics before and after three years of planting. Survival rate was indicated by the percentage of plants that survived divided by the total number of planted plants. Plant's height was consistently measured from the ground level to the highest top of the plant, while the diameter was measured at $\quad \pm 10$ $\mathrm{cm}$ above ground level.

\section{Analysis}

ANOVA (analysis of variance) was performed to identify species performances among the ten local plant species. It was followed by Tukey HSD test if the analysis of variance showed a significant difference between variables. The ANOVA result tables will not be shown, but the results of the Tukey HSD Test will be shown in histograms, and the statistical difference will be distinguished by letters. Before the analysis of variance, the data were tested to identify the normality, and if the data were not distributed normally, then they will be transformed using logarithms. Beside ANOVA, the height and diameter growth data are also depicted by using a graphic to observe the growing patterns.

\section{RESULT AND DISCUSSION}

\section{A. Plant Survival Rates of the 10 Local Tree Species in the Post-Coal Mining Land}

The results showed that seven of the ten local plant species planted on the post-coal mining area had survival rates above $80 \%$ at the age of four years. Among seven species, three of them had a survival rate above $90 \%$, i.e. S. polyanthum, 
S. scortechinii and V. pinnata (Figure 2). Survival rate indicates the number of surviving plants in the research site, including plants that grow slowly or it is in static growth. There were also three species having survival rates below $70 \%$; i.e. F. variegata, B. glauca and S. wallichii, in which F. variegata had the lowest value, $32 \%$.

In the first observation year, these three plant species also had low survival rates compared to the other seven local plants planted on the research site (Adman \& Yassir, 2016). However, in general, plant death had occurred to almost all species of plants observed from 1 year to 4 years. It is indicated by a decrease in the plant's survival rate, except for $V$. pinnata, which showed consistently 100\% survival rate. This means that death has occurred to the nine species of plants at a different rate. The decrease in the survival rate of plants indicates that some species were unable to adapt to the extreme mining environment at a different level. The reduction in survival rate from the 1 to 4 year varied between the ten local plant species. Five species have a decrease rate of less than $10 \%$, i.e. S. lineatum (1.67\%), S. scortechinii $(2.50 \%)$, S. wallichii $(3.34 \%)$, C. myrianthus $(4.17 \%)$ and $S$. polyanthum (6.66\%). The other species have a decrease rate below $20 \%$, i.e. S. balangeran (13.33\%), M. motleyana $(15.00 \%)$ and B. glauca (16.67\%). Meanwhile, F. variegata has the highest decrease rate of $36.50 \%$.

Analysis of variance on the survival rate of the ten local tree species showed that the survival rate between species was significantly different. The result of multiple range tests and the details of plant survival rates are presented in Figure 2.

\section{B. The Average Height and Diameter Growth of the Ten Local Tree Species in the Post-Coal Mining Land}

From ANOVA, it can be said that there were significant differences in terms of height and diameter growth rate among the ten local plant species tested in this study, as indicated in the results of multiple range tests (Figures 3 and 4). From the figures, several groups can be categorized by the plant growth in terms of height or diameter. The first group was $V$. pinnata, which had the most significant growth both in height and diameter compared to the other nine plant species during the four years. It grew by almost $5 \mathrm{~m}$ in height and $7.22 \mathrm{~cm}$ in diameter. Meanwhile, $S$. polyanthum, $S$. balangeran and S. scortechinii can be categorized as the second most impressive species in terms of height growth, with about $3 \mathrm{~m}$ growth in the four years. The third group of growth in terms

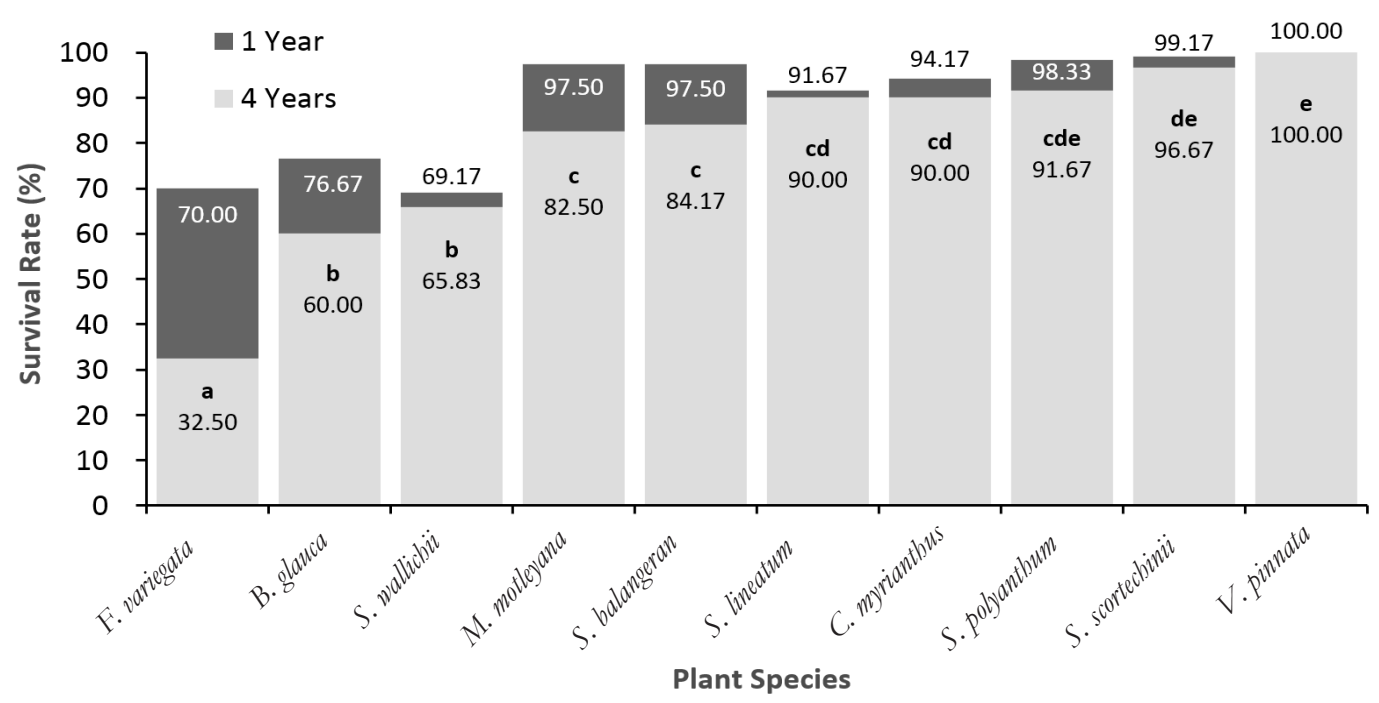

Figure 2. The survival rates of ten local tree species at years 1 and 4 in post-coal mining land, PT SGP

(The same letters are not significantly different at 95\% confidence level in Tukey HSD Test) 


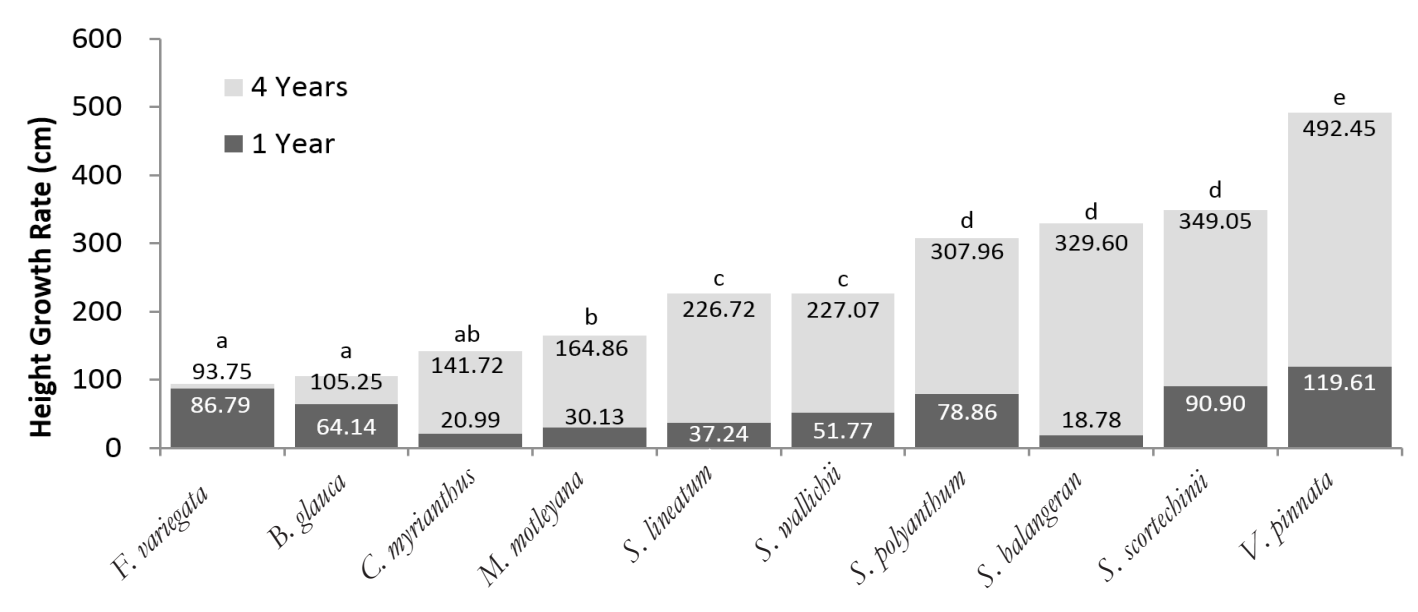

Plant Species

Figure 3. The height growth of ten local tree species at four years in post-coal mining land, PT SGP (The same letters are not significantly different at 95\% confidence level in Tukey HSD Test)

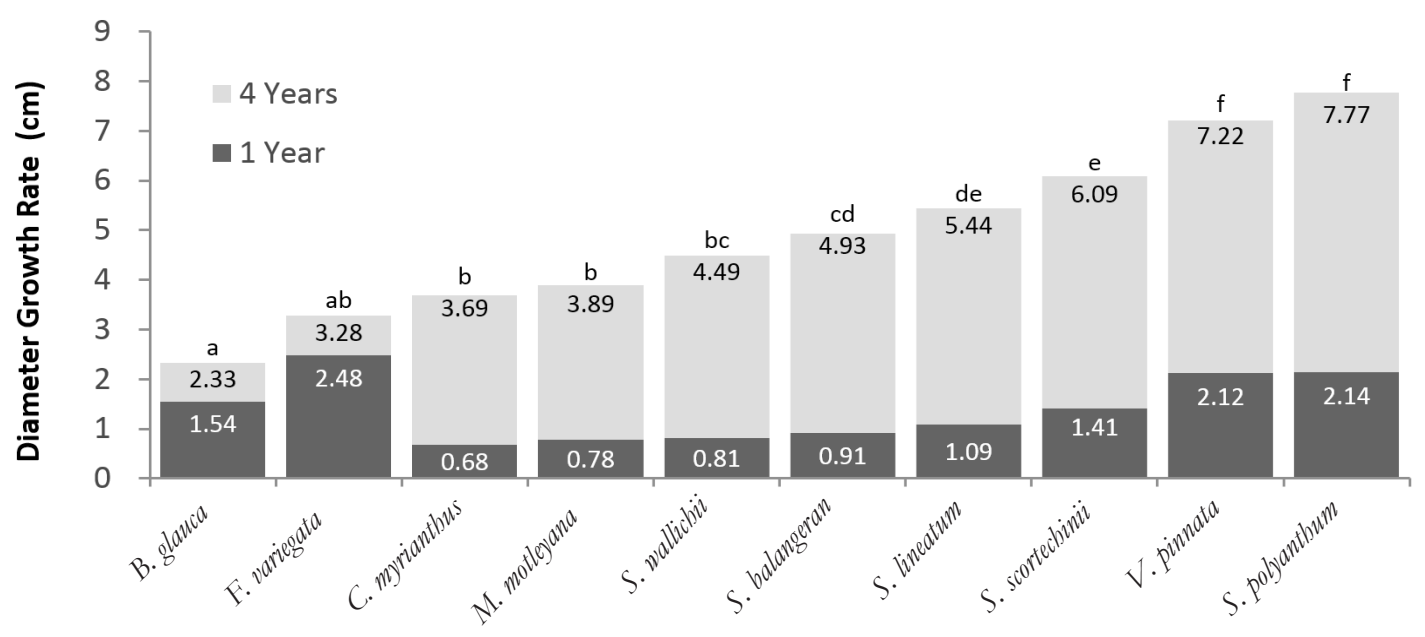

Plant Species

Figure 4. The diameter growth of ten local tree species at four years in post-coal mining land, PT SGP (The same letters are not significantly different at 95\% confidence level in Tukey HSD Test)

of height was $S$. lineatum and S. wallichii, then followed by C. myrianthus and M. motleyana as the fourth group.

In terms of diameter, $S$. polyanthum can be categorized as the most impressive because its growth is close to $V$. pinnata, growing by about $7 \mathrm{~cm}$ during the four years. Meanwhile, $S$. balangeran, $S$. lineatum and $S$. scortechinii can be placed in the same group, with diameter growth range from 4.9 to $6 \mathrm{~cm}$ in the same period. The next group is C. myrianthus, $M$. motleyana and S. wallichii, with diameter growth from
3.5 to $4.5 \mathrm{~cm}$ during the same period. The last group is F. variegata and B. glauca, which can be considered to have the slowest growth, in terms of height and diameter compared to the other species.

\section{The Growth Pattern of the Ten Local Plant Species in the Post-Coal Mining Land}

The growth pattern of ten local plant species is presented in Figures 5 and 6. From the figures, in general, all species observed in this study 
experienced slow growth in terms of height and diameter in the first year after planting. In the following years, there was an acceleration in both height and diameter growth at various rates of almost all plant species observed. If we study the growth pattern in more detail, the growth acceleration occurred from month $12^{\text {th }}$ to $30^{\text {th }}$. In the subsequent months, particularly from months $30^{\text {th }}$ to $36^{\text {th }}$, the height and diameter growth was slower than in the previous period. Finally, in the subsequent period, from months $36^{\text {th }}$ to $48^{\text {th }}$, the height and diameter growth began to accelerate, except for B. glauca.

In Figures 5 and $6, V$. pinnata had shown a consistent and significant growth pattern in both diameter and height compared to the other plant species. Furthermore, although the diameter growth began to de-accelerate at the $30^{\text {th }}$ months, this species' height growth is started to re-accelerate again in the $36^{\text {th }}$ month. Meanwhile, S. balangeran's height growth shows different pattern compared to the other species, after experiencing rapid growth during the first 30 months period, the height growth stagnated instead of growing from month $30^{\text {th }}$ to $36^{\text {th }}$. This is because of a significant number of $S$. balangeran were experiencing 'partial death' during that time; therefore, the heights were measured at the new part of the plants that just grew from month $30^{\text {th }}$ to month $48^{\text {th }}$. Partial death means that part of the total height of the plant is dead, which is followed by the growth of several new shoots in the plants in the subsequent period. On the other hand, B. glauca and F. variegata show different height growth pattern. After a slow growth in the first two years, they experienced stagnation in height growth from $24^{\text {th }}$ month to $48^{\text {th }}$ month, which was also caused by partial death in some plants.

In Figure 6, S. polyanthum, $V$. pinnata, and $S$. scortechinii have similar diameter growth pattern, showing the most significant and consistent growth up to the first $30^{\text {th }}$ month and slightly decreasing in the subsequent 18 months, compared to the other species. Meanwhile, $B$. glauca and F. variegata show relatively similar diameter growth pattern with their height growth pattern. The slow diameter growth of the two species has occurred up to month $30^{\text {th }}$. While F. variegata experienced a slight increase in the diameter growth from month $30^{\text {th }}$ to $36^{\text {th }}$ followed by a continued stagnation (the tree cannot grow negatively) up to month $48^{\text {th }}$, B. glauca had experienced a steady decrease in diameter growth since month $30^{\text {th }}$.

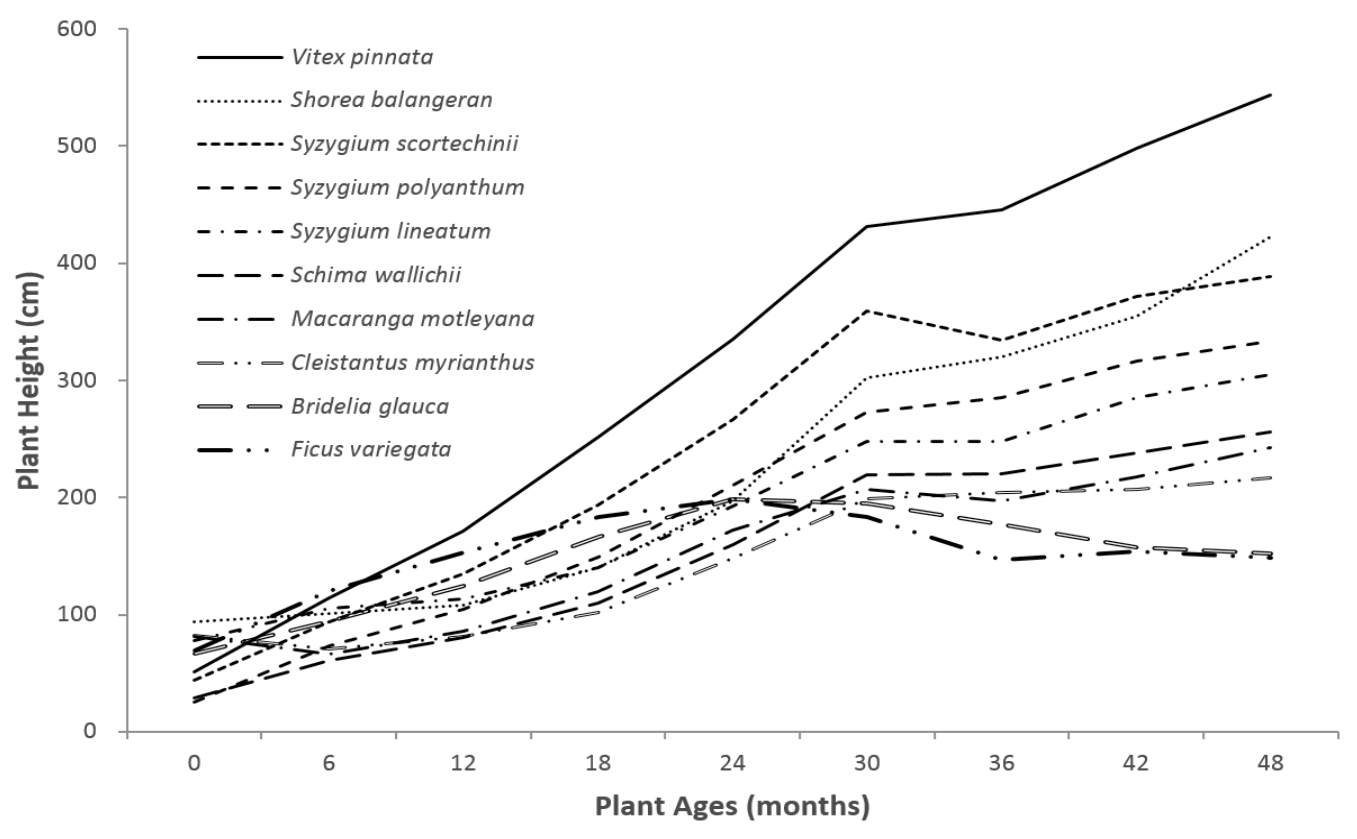

Figure 5. Height growth trends of ten local tree species after four years planted in post-coal mining land, PT SGP 


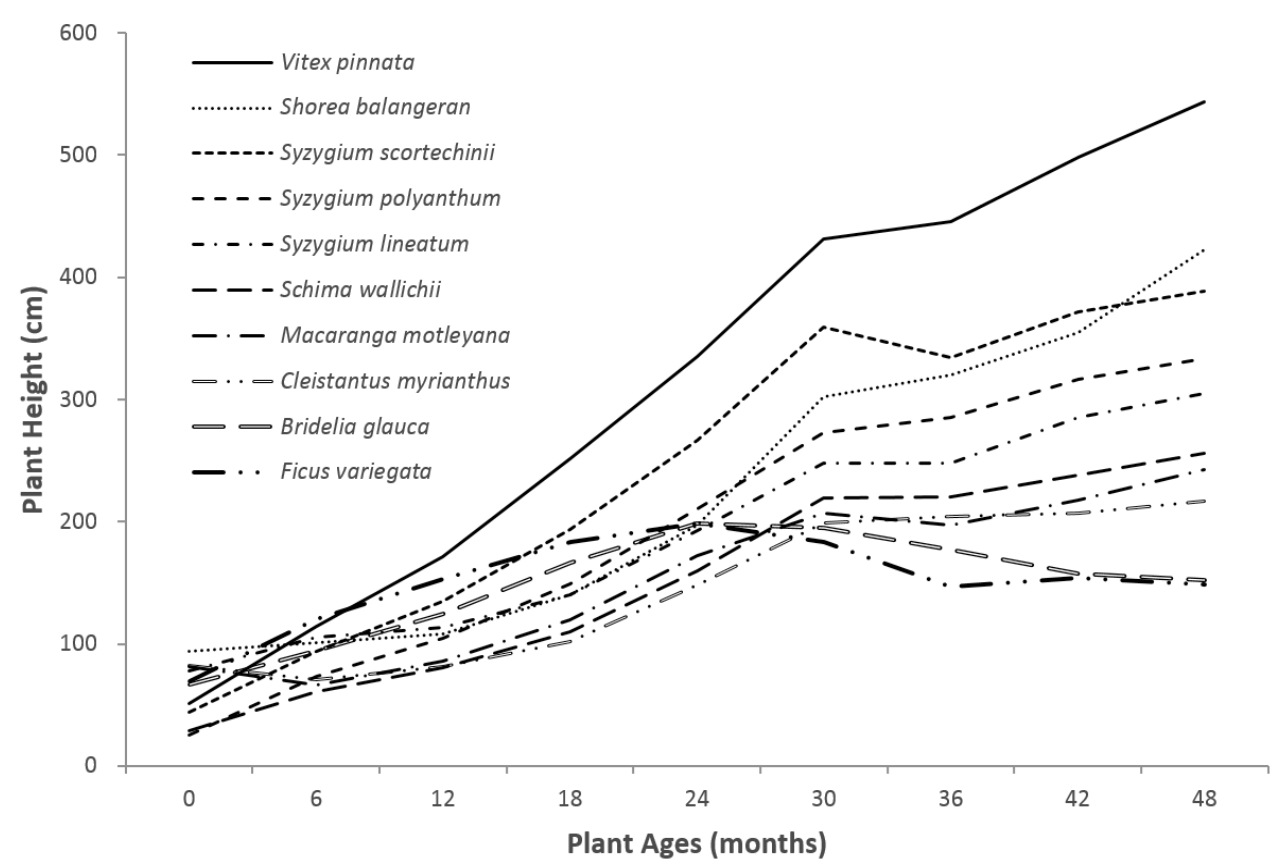

Figure 6. Diameter growth trends of ten local tree species after four years planted in post-coal mining land, PT SGP

\section{Plant Adaptation to the Environment of Rehabilitation Area}

The main cause of the slow growth of almost all species of plants in the first year was due to the adaptation process from the nursery to the rehabilitation area. There were dramatic environmental changes from the nursery, in which the plants were kept before planted into the mining area, which is characterized by an open area, water-shortage, extremely high temperature, and soil compaction. On the other hand, in the nursery, the plants were controlled in a relatively cool temperature and well maintained. Furthermore, there is four typologies of soil degradation; highly degraded lands, moderately degraded lands, slightly degraded lands and improving lands (FAO, 2011). The severity of soil degradation in the post-mining areas can be categorized as highly degraded; in this type of degradation, the intervention option needed is rehabilitation. As a result, some plant species might need considerable time to adapt to the rehabilitation area.

Stressful environmental condition like water shortage in the post-coal mining areas during the first year of rehabilitation might result in a decrease in the amount of chlorophyll in the leaves of the plants (Ramírez et al., 2014). Death can occur to the plants; simply, they did not survive. However, the survived plants would re-sprout and re-grow. Nevertheless, some of the local tree species planted could re-sprout, but each of the plant species had different times to re-sprout and re-grow. Therefore, the ability to re-sprout is important for plants to survive and grow in post-coal mining land as a form of adaptation to extreme environmental conditions.

The other abiotic stress in the postcoal mining rehabilitation areas is the high temperature. A review reported that heat stress has some negative impacts on plants, depending on species types, genotype and heat duration (Bita \& Gerats, 2013). From the review, there are several visible impacts to the plants resulting from high temperature; burned or senescence leaves and stems, damage of fruit and suppressing root growth leading to plant productivity loss. The review also reveals that heat stress can change the respiration and photosynthesis of the plants, causing a 
decrease in plant productivity and shortened life cycle. It is also shown that a $5^{\circ} \mathrm{C}$ increase in temperature above the normal condition can lead to a reduction in protein synthesis in the cellular system. Besides, heat stress also has some adverse impact on the molecular level of plants affecting the photosynthesis (Allakhverdiev et al., 2008). In the ecosystem, heat stress can cause tree mortality in the forest ecosystem (Anderegg, Kane, \& Anderegg, 2013). Therefore, the slow growth of the ten local species in the first year after planting was caused by high temperature.

Although the analysis of the physical properties of the soil was not done, the issue of soil compaction is also one of the main features that potentially inhibiting plant growth. A review reported that severe soil compaction could result in stunted growth of shoot, root deformation and high mortality rate (Nawaz, Bourrié, \& Trolard, 2013). From the review, it was also revealed that soil compaction also reduced the soil biodiversity; reducing the number of soil fauna and flora, enzymatic activity and microbial biomass. Moreover, a study reported that there were significant differences in terms of soil microbial communities between soil from postmining areas and undisturbed soil, in which the controlled soil areas had higher microbial diversity compared to the soil of post-mining regions (de Quadros et al., 2016). However, another research showed that there was no difference in terms of growth and survival rates between trees planted in compacted soil and un-compacted soil in the post-mining areas in West Virginia, the USA (Emerson, Skousen, \& Ziemkiewicz, 2009). This might be due to the age of seedlings planted in the study, which was two years old. Meanwhile, in this study, the age of the seedlings when they were planted was unknown because the seedlings were obtained from the natural forests. Thus, the compacted soil in this study might have a negative impact on plant growth, resulting in slow diameter and height development in the first year.

The analysis of soil chemical properties (Table 2) shows that among species, the $\mathrm{pH}$ values were generally very acid and decreased from 3.83-4.57 to 3.38-4.06. The Cation Exchange Capacities (CEC) varies, some have increased, and some dropped, although all are still in the low category. The $\mathrm{N}$ total increased under several species from very low to the standard type; otherwise, the $\mathrm{C} / \mathrm{N}$ ratio generally decreased. The concentration of $\mathrm{P}_{2} \mathrm{O}_{5}$ and $\mathrm{K}_{2} \mathrm{O}$ were growing, especially for $\mathrm{K}_{2} \mathrm{O}$ that significantly increased, from low-medium to high-very high.

\section{E. Plant Growth}

During four years, $V$. pinnata had a remarkable growth performance, indicated by reasonable survival rate, diameter and height growth, compared to the other nine species. This species also had relatively better adaptation to the environment in the early

Table 2. Local plant species planted in this study

\begin{tabular}{|c|c|c|c|c|c|c|c|c|c|c|c|c|c|}
\hline \multirow[t]{2}{*}{ No } & \multirow[t]{2}{*}{ Species } & \multicolumn{2}{|c|}{$\mathrm{pH}$} & \multicolumn{2}{|c|}{$\begin{array}{c}\mathrm{CEC} \\
\text { (meq./100 gr) }\end{array}$} & \multicolumn{2}{|c|}{ N Total } & \multicolumn{2}{|c|}{$\mathrm{C} / \mathrm{N}$ ratio } & \multicolumn{2}{|c|}{$\begin{array}{c}\text { P2O5 } \\
(\mathrm{ppm})\end{array}$} & \multicolumn{2}{|c|}{$\begin{array}{l}\mathrm{K} 2 \mathrm{O} \\
(\mathrm{ppm})\end{array}$} \\
\hline & & $\mathrm{r}$ & Years & 0 Year & 3 Years & 0 Year & 3 Years & & & & 3 Years & 0 Year & 3 Years \\
\hline 1. & Vitex pinnata & ( & $38^{1)}$ & $5.62^{\mathrm{b})}$ & & $0.04^{\mathrm{a})}$ & $0.11^{\mathbf{b})}$ & 20.1 & & 0.86 & $5.71^{\mathrm{a})}$ & 20b) $-2+2$ & \\
\hline 2. & Sysygium polyanthum & & $60^{1)}$ & $b^{b)}$ & 7.8 & a) & & & & & & & \\
\hline 3. & Cleistanthus & & & & & & & & & & & & \\
\hline 4. & Sysygium lin & & $3.82^{1)}$ & $6.16^{\mathrm{b})}$ & $7.41^{b)}$ & $0.06^{\mathrm{a})}$ & & 14. & & $0.77^{\text {a) }}$ & 2.4 & $8.18^{\mathrm{a})}$ & $67^{\text {d) }}$ \\
\hline 5. & Syaygium sco & & & $7.45^{\mathrm{b})}$ & & $0.06^{\mathrm{a})}$ & & 14. & & $0.94^{\text {a) }}$ & 2.4 & & \\
\hline & Bridelia glauc & & & $7.06^{\mathrm{b})}$ & 6.70 & 0.00 & & 15 & c) & 1.2 & & $6^{\mathrm{b})} 3$ & \\
\hline & Ficus varie & & $3.86^{1)}$ & $7.08^{\mathrm{b})}$ & $6.93^{b)}$ & $0.05^{\mathrm{a})}$ & $\left.0.10^{\mathrm{b}}\right)$ & $17.5^{\mathrm{d})}$ & & $0.86^{\mathrm{a})}$ & 0.65 & $13.01^{\mathrm{b})}$ & $23.74^{\mathrm{c})}$ \\
\hline & Schima wallichii & & & & & & 0.0 & & & 1.2 & $2.47^{\mathrm{a})}$ & $20.52^{\mathrm{b})}$ & \\
\hline & $M$ & & & $7.31^{\mathrm{b})}$ & $7.29^{\mathrm{b})}$ & $0.06^{\mathrm{a})}$ & & $13.7^{\mathrm{c})}$ & 14.0 & 2.1 & 4.4 & $17.49^{\mathrm{b})}$ & $47.33^{\mathrm{d})}$ \\
\hline 10. & Shorea balangeran & $4.52^{2)}$ & $3.69^{1)}$ & $4.84^{\mathrm{b})}$ & $6.32^{\mathrm{b})}$ & $0.07^{\mathrm{a})}$ & $\left.0.07^{a}\right)$ & $9.5^{\mathrm{b})}$ & $10.12^{\mathrm{b})}$ & $0.86^{\mathrm{a})}$ & $2.47^{\mathrm{a})}$ & $32.38^{\mathrm{c})}$ & $41.19^{\mathrm{d})}$ \\
\hline
\end{tabular}

Remarks: ${ }^{1)}$ Very acid; ${ }^{2)}$ Acid; ${ }^{\text {a) }}$ Very Low; ${ }^{\text {b) Low; }}{ }^{\text {c) }}$ Medium; ${ }^{\text {d) }}$ High; ${ }^{\text {e) }}$ Very High (Based on Hardjowigeno, 1995) 
stage of the rehabilitation process, which can be shown in the consistent trend of diameter and height growth (Figure 5 and 6) during the four years. $V$. pinnata was one of the dominant plant species in the regeneration process of the tropical rainforest after fire disturbances, which therefore was categorized as a pioneer species (Yassir, van der Kamp, \& Buurman, 2010).

From their study, it can be indicated that $V$. pinnata requires a significant amount of sunlight to grow, which is abundantly available at the post-coal mining land at the beginning of the planting process. There was the limited study about the growth of $V$. pinnata, but a study showed that this species is one of the most adaptive plant species growing in the post-tin mining areas in Bangka, Indonesia (Nurtjahya, Franklin, Umroh, \& Agustina, 2017). However, if compared to other fast-growing pioneer species such as Paraserianthes falcataria, V. pinnata has significantly lower height and diameter growth. P. falcataria, which is an exotic species, can reach 3.4-16.7 cm of diameter and 3.9-19.6 $\mathrm{m}$ of height at the age of about four years in West Java, Indonesia (Krisnawati, Varis, Kallio, \& Kanninen, 2011). Nevertheless, the use of fast-growing exotic species in the rehabilitation of post-coal mining area is allowed based on regulations in Indonesia. However, it might have some consequences for biodiversity conservation (Nugroho \& Yassir, 2017).

In this study, F. variegata and B. glauca had poor growth performance, which can be indicated by low survival rates and slowest diameter and height growth among the other species. F. variegata, has been used in some tropical forest restoration projects because of its role as a keystone species (Kuaraksa \& Elliott, 2013) and pioneer (Kuaraksa, Elliott, \& HossaertMckey, 2012). Still, this species seemed unable to adapt in the post-coal mining environment. For example, at the age of 2 years, the growth of F. variegata was $6-8 \mathrm{~cm}$ diameter, and 6.9 $\mathrm{m}$ height in Java applied in the intercropping system (Effendi, 2012). In another study, this species can reach $6.2 \mathrm{~cm}$ diameters and $5.1 \mathrm{~m}$ height in East Kalimantan in a monoculture planting system (Effendi \& Mindawati, 2015).
However, the levels of soil degradation in the intercropping and monoculture systems were different than the soil degradation in the post-coal mining areas. The soil in the postmining area has experienced the heaviest soil degradation compared to the other methods because of heavy machinery activities during surface removal. As a result, the environmental stress in the post-coal mining areas is more intense than ecological stress in theintercropping and monoculture systems, resulting in the slow growth of F. variegata.

The inability to adapt in the post-mining areas might also be the case for the poor growth performance of B. glauca. Other study showed that $B$. glauca, along with $V$. pinnata, was one of the dominant plant species identified in a secondary forest after ten years regeneration from imperata grassland because of fire disturbances, indicating that B. glauca is a pioneer species, demanding direct sunlight for supporting its growth which is abundantly available in the post-mining areas (Komara, Murtinah, \& Arbain, 2018; Yassir, 2016). Meanwhile, this species was found in a succession area of degraded forest (Gunawan, 2015). However, B. glauca might not be able to grow naturally in the heavily degraded soil such as in the post-coal mining areas. Nevertheless, the information about the growth of B. glauca is limited; therefore, it is difficult to compare its growth. A study reported that B. glauca could grow to a height of up to $10 \mathrm{~m}$, initially distributed in Okinawa, Japan, Taiwan, Southern part of China, Indochina and the Philippines (Ngueyem, Brusotti, Caccialanza, \& Finzi, 2009).

Meanwhile $S$. polyanthum had the most massive diameter growth but moderate height growth compared to the other nine plant species. However, S. polyanthum growth in this study was remarkable compared to other studies. A study reported the diameter growth of $S$. polyanthum planted in the restoration of degraded forest in Singapore can reach about $1 \mathrm{~cm}$ per year with the average diameter of about $3.5 \mathrm{~cm}$ at the age of 4 years (Shono, Davies, \& Chua, 2007). The other study showed that at the period of 14 
months, $S$. polyanthum had $29.06 \mathrm{~cm}$ of height and $0.7 \mathrm{~cm}$ of diameter, which was planted in a nature tourism park degraded area with the intercropping system (Sumarhani, 2015). Thus, by considering the level of degradation, which is heavier in the post-coal mining areas than the level of degradation in the other studies, $S$. polyanthum might be able to adapt to the postmining regions in this study. This species is also known as a medicinal plant (Har \& Intan, 2012; Widyawati et al., 2015).

The other species in this study, Sh. balangeran, S. lineatum and S. scortechinii showed consistent moderate diameter and height growth compared to the other species. S. balangeran showed a significant increase in diameter and height growth which occurred since the month $42^{\text {nd }}$, after a slow growth during the first 12 months. This indicates that this species might grow well in the post-mining environment. However, the development of $S$. balangeran in the first year in this study is slower compared to several studies. A similar study reported that $S$. balangeran could grow by $19 \mathrm{~cm}$ in height and $0.5 \mathrm{~mm}$ in diameter during the first year, grown under the shaded area of 4 years old fast-growing plants, Samanea saman (Susilo, 2016), and another study show it grows by 146-149 $\mathrm{cm}$ of height and $1.5-3.0 \mathrm{~cm}$ of diameter at five years old in post-coal mining land (Lestari, Fiqa, Fauziah, \& Budiharta, 2019). This indicates that shaded areas are essential for $S$. balangeran during the first years after planting in the post-mining environment.

On the contrary, another study reported that S. balangeran could grow well in the un-shaded imperata grassland, growing by $64-71 \mathrm{~cm}$ of height and $8-10 \mathrm{~mm}$ in diameter at the first year at various land preparations (Yassir \& Mitikauji, 2007). It is important to note that the level of degradation in the imperata grassland was much lower than the level of degradation in the post mining areas, causing significant growth of $S$. balangeran in the first year. In addition, this species is also reported as one of the plants for peat swamp restoration project (Graham, Turjaman, \& Page, 2013). Furthermore, S. balangeran was said to have about $2.7 \mathrm{~cm}$ of stem diameter at the age of
40 months, planted in the peat swamp forest in Central Kalimantan (Turjaman et al., 2011), slightly lower than the diameter growth in this research. This indicates that $S$. balangeran can grow in various environments.

Compared to the other studies, the diameter and height growth of $S$. lineatum in this study was acceptable. A study reported that this species could grow by $0.28 \mathrm{~cm}$ in height and $0.76 \mathrm{~cm}$ in diameter in the first year (Rahman et al., 2011). Meanwhile, in this study, the height and diameter growth of $S$. lineatum was stagnated during the first year but started to grow consistently from the $2^{\text {nd }}$ to $4^{\text {th }}$ year. This indicates that this species can adapt and grow in a heavily degraded environment such as in the post-mining areas.

Furthermore, S. lineatum can also grow in the succession areas in an abandoned grazing site in West Java, Indonesia (Rosleine \& Suzuki, 2012). This indicates that this species is pioneer species-meanwhile, works of literature about Sy. Scortechinii is limited; therefore, it is hard to compare its growth in another environment.

The other species; S. wallichii, M. motleyana and $C$. myrianthus had low to the average but the consistent diameter and height growth in the four years compared to the other species. However, it is difficult to evaluate the growth performance of these three species due to limited works of literature. Based on available pieces of literature, S. wallichii, M. motleyana and C. myrianthus can be categorized as pioneer species, appearing after disturbances in a forest ecosystem. For example, $S$. wallichii was reported appearing in an abandoned coal mining site in India, in which the coal extraction was conducted using 'rat-hole' mining method (Sarma, Kushwaha, \& Singh, 2010). The other study showed that $S$. wallichii grows in a natural succession area after the volcanic eruption, although this species was not a dominant plant (Suryanto, Zaki, Azani, \& Azmy, 2010).

Meanwhile, another study shows that C. myrianthus was a plant species in the secondary forests (Yusuf \& Purwaningsih, 2012). Also, M. motleyana was a pioneer species that reported to dominantly inhabit the low to intermediate 
disturbance (Slik, Keßler, \& van Welzen, 2015) level forest. Nevertheless, in the high level of disturbances such as mining activities in this study, in which the soil experience compaction, these tree species might still be able to grow, but they need time to adapt to the post-mining environment during the first year.

Increasing plant growth needs input technology. Soil management that preserves soil nutrients and prevents acidification is likely key to the success of reforesting postmining land (Woodbury et al., 2020). The use of mycorrhizae can be a solution to improve soil quality and plant growth. Application of mycorrhizae could improve some chemical soil properties such as $\mathrm{pH}$, soil organic $\mathrm{C}$, total soil $\mathrm{N}$, and available P (Agus, Primananda, Faridah, Wulandari, \& Lestari, 2019; Wulandari, Saridi, Cheng, \& Tawaraya, 2016).

\section{CONCLUSION}

In conclusion, almost all plant species in this study have been able to grow and to adapt to the post-coal mining land, and only 2 out of 10 species were unable to adapt in this environment. In this study, $V$. pinnata had the most significant growth performance compared to the other nine species. S. polyanthum, S. scortechinii and $S$. lineatum also had a good growth performance in the post-coal mining land. Even though as a climax forest species, $S$. balangeran had an excellent performance in an open area such as post-coal mining land.

In the early period after plantation, all species experienced slow growth due to adaptation to the post-mining environmental condition, after 12 months the development of the ten species increased at a variable rate. Only two species; B. glauca and F. variegata experienced a decrease in diameter and height growth two years after planted.

V. pinnata, S. polyanthum, S. scortecbinii, $S$. lineatum, and $S$. balangeran can be recommended as revegetation plants for the rehabilitation of post-coal mining land. Trials should be undertaken on other local trees and local climax trees to support the success of the rehabilitation of post-coal mining land mainly located in the forest area.

\section{ACKNOWLEDGEMENT}

The authors would like to thank the leaders and employees of PT Singlurus Pratama, which helped the field implementation of this study. Also thanks to Yusuf Wibisono, Mujianto, Ermansyah, Deny Adi Putra, Suhardi, Agung Siswanto and Iman Suharja who helped in collecting data in the field. The authors are also very grateful to the Chairman of Balitek KSDA and staff who helped in the administration process of the study. This study was funded by DIPA Balitek KSDA during 2012-2016 financial years.

\section{REFERENCES}

Adman, B., \& Yassir, I. (2016). Rehabilitasi lahan bekas tambang batubara menggunakan sepuluh jenis lokal. Indonesian Forest Rehabilitation Journal, 4(2), 73-83.

Agus, C., Primananda, E., Faridah, E., Wulandari, D., \& Lestari, T. (2019). Role of arbuscular mycorrhizal fungi and Pongamia pinnata for revegetation of tropical open-pit coal mining soils. International Journal of Environmental Science and Technology, 16, 3365-3374. doi://10.1007/s13762-018-1983-5.

Allakhverdiev, S. I., Kreslavki, V. D., Klimov, V. V, Los, D. A., Carpentier, R., \& Mohanty, P. (2008). Heat stress: An overview of molecular responses in photosynthesis. Photosynthesis Research, 98(1-3), 541-550. doi://10.1007/s11120-008-9331-0.

Anderegg, W. R.; Kane, J. M.; Anderegg, L. D. (2013). Consequences of widespread tree mortality triggered by drought and temperature stress. Nature Climate Change, 3(1), 30-36.

Bita, C. E., \& Gerats, T. (2013). Plant tolerance to high temperature in a changing environment: Scientific fundamentals and production of heat stress-tolerant crops. Frontiers in Plant Science. 4, 1-18. doi://10.3389/ fpls.2013.00273.

de Quadros, P. D., Zhalnina, K., Davis-Richardson, A. G., Drew, J. C., Menezes, F. B., Flávio, A. 
D. O., \& Triplett, E. W. (2016). Coal mining practices reduce the microbial biomass, richness and diversity of soil. Applied Soil Ecology, 98, 195-203.

Effendi, R. (2012). Kajian keberhasilan pertumbuhan tanaman Nyawai (Ficus variegata Blume) di KHDTK Cikampek, Jawa Barat. Jurnal Penelitian Hutan Tanaman, 9(2), 95-104.

Effendi, R., \& Mindawati, N. (2015). Budidaya jenis pohon Nyawai (Ficus variegata Blume.). Kementerian Lingkungan Hidup dan Kehutanan, Bogor.

Emerson, P., Skousen, J., \& Ziemkiewicz, P. (2009). Survival and growth of hardwoods in brown versus gray sandstone on a surface mine in West Virginia. Journal of Environment Quality, 38(5), 1821-1829. doi://10.2134/ jeq2008.0479.

FAO. (2011). The state of the world's land and water resources for Food and Agriculture (SOLAW) - Managing systems at risk. In The Food and Agriculture Organization of the United Nations and Earthscan. doi://978-1-84971326-9.

Graham, L. L. B., Turjaman, M., \& Page, S. E. (2013). Shorea balangeran and Dyera polyphylla (syn. Dyera lowii) as tropical peat swamp forest restoration transplant species: Effects of mycorrhizae and level of disturbance. Wetlands Ecology and Management, 21(5), 307321. doi://10.1007/s11273-013-9302-x.

Gray, A. (2002). The evolutionary context: A species perspective (Vol. 1). Cambridge: Cambridge University Press.

Gunawan, H. (2015). Suksesi sekunder hutan terganggu bekas perambahan di Taman Nasional Gunung Ciremai, Jawa Barat. Prosiding Seminar Nasional Masyarakat Biodiversitas Indonesia, 1591-1599. Masyarakat Biodiversitas Indonesia, Malang.

Har, L., \& Intan, S. I. (2012). Antioxidant activity, total phenolics and total flavonoids of Syzygium polyanthum (Wight) Walp leave. International Journal of Medicinal and Aromatic Plants, 2(2), 219-228.

Ishak, A. F. (2013). Visi Kaltim 2030: Pertumbuhan Kaltim hijau yang berkeadilan dan berkelanjutan: sebuah pemikiran kebijakan transformasi ekonomi pasca migas dan batubara. Pemerintah Provinsi Kalimantan Timur, Samarinda.
Istomo, Setiadi, Y., \& Putri, A. N. (2013). Evaluasi keberhasilan tanaman hasil revegetasi di lahan pasca tambang batubara site lati PT. Berau Coal Kalimantan Timur. Jurnal Silvikultur Tropika, 04(2), 77-81.

Komara, L. L., Murtinah, V., \& Arbain. (2018). Evaluation of plant species composition after thirteen years of post-coal mining rehabilitation in East Kutai District of East Kalimantan, Indonesia. IOP Conference Series: Earth and Environmental Science. doi://10.1088/1755-1315/144/1/012057.

Krisnawati, H., Varis, E., Kallio, M., \& Kanninen, M. (2011). Paraserianthes falcataria (L.) Nielsen. ekologi, silvikultur dan produktivitas. CIFOR, Bogor.

Kuaraksa, C., \& Elliott, S. (2013). The use of asian ficus species for restoring tropical forest ecosystems. Restoration ecology. doi://10.1111/ j.1526-100X.2011.00853.x.

Kuaraksa, C., Elliott, S., \& Hossaert-Mckey, M. (2012). The phenology of dioecious Ficus spp. tree species and its importance for forest restoration projects. Forest Ecology and Management. 265, 82-93. doi://10.1016/j. foreco.2011.10.022.

Kusmana, C., Setiadi, Y., \& Al-Anshary, M. A. (2013). Studi pertumbuhan tanaman hasil revegetasi di lahan pasca tambang batubara PT. Arutmin Indonesia site Batulicin Kalimantan Selatan. Jurnal Silvikultur Tropika, 4(3), 160-165.

Lestari, D. A., Fiqa, A. P., Fauziah, \& Budiharta, S. (2019). Growth evaluation of native tree species planted on post-coal mining reclamation site in East Kalimantan, Indonesia. Biodiversitas, 20(1), 134-143. doi://10.13057/biodiv/d200116.

Mansur, I. (2010). Teknik silvikultur untuk reklamasi lahan bekas tambang. Seameo Biotrop, Bogor.

Merem, C. E., Isokpehi, P., Wesley, J., Nwagboso, E., Richardson, C., Fageir, S., ... Crisler, M. (2014). The analysis of coal mining impacts on West Virginia's environment. British Journal of Applied Science \& Technology, 4(8), 1171-1197.

Mushia, N., Ramoelo, A., \& Ayisi, K. (2016). The impact of the quality of coal mine stockpile soils on sustainable vegetation growth and productivity. Sustainability, 8(6), 546. 
Nawaz, M. F., Bourrié, G., \& Trolard, F. (2013). Soil compaction impact and modelling. A review. Agronomy for Sustainable Development. 33, 291309. doi://10.1007/s13593-011-0071-8.

Ngueyem, T. A., Brusotti, G., Caccialanza, G., \& Finzi, P. V. (2009). The genus Bridelia: A phytochemical and ethnopharmacological review. Journal of Ethnopharmacology. 124(3)339-349.doi://10.1016/j. jep.2009.05.019.

Nugroho, A. W., \& Yassir, I. (2017). Kebijakan penilaian keberhasilan reklamasi lahan pasca-tambang batubara di Indonesia. Jurnal Analisis Kebijakan Kebutanan, 14(2), 121-136.

Nurtjahya, E., Franklin, J., Umroh, \& Agustina, F. (2017). The impact of tin mining in Bangka Belitung and its reclamation studies. MATEC Web of Conferences. 101, doi://10.1051/ matecconf/201710104010.

Pandey, B., Agrawal, M., \& Singh, S. (2014). Coal mining activities change plant community structure due to air pollution and soil degradation. Ecotoxicology, 23(8), 1474-1483. doi://10.1007/s10646-014-1289-4.

Radiansyah, A. D., Susmianto, A., Siswanto, W., Tjitrosoedirdjo, S., Djohor, D. J., Setyawati, T., ... Gunadharma, N. (2015). Strategi nasional dan arahan rencana aksi pengelolaan jenis asing invasif di Indonesia. Deputi Bidang Pengendalian Kerusakan Lingkungan dan Perubahan Iklim, Kementerian Lingkungan Hidup dan Kehutanan, Republik Indonesia.

Rahman, W., Kurniawati, F., Iskandar, E. A., Hidayat, I. W., Widyatmoko, D., \& Ariati, S. R. (2011). Survivorship and growth of eight native tree species during their early stage at a restored land within Gede Pangrango National Park, Indonesia. Prosiding Seminar Nasional Konservasi Tumbuban Tropika: Kondisi Terkini dan Tantangan ke Depan, 500-505. Cibodas: Balai Konservasi Tumbuhan Kebun Raya Cibodas, LIPI.

Ramírez, D. A., Yactayo, W., Gutiérrez, R., Mares, V., De Mendiburu, F., Posadas, A., \& Quiroz, R. (2014). Chlorophyll concentration in leaves is an indicator of potato tuber yield in water-shortage conditions. Scientia Horticulturae. 168, 202-209. doi://10.1016/j. scienta.2014.01.036.

Rosleine, D., \& Suzuki, E. (2012). Secondary succession at abandoned grazing sites,
Pangandaran Nature Reserve, West Java, Indonesia. Tropics, 21(3), 91-104.

Sarma, K., Kushwaha, S., \& Singh, K. J. (2010). Impact of coal mining on plant diversity and tree population structure in Jaintia Hills District of Meghalaya, North East India. New York Science Journal, 3(9), 79-85.

Shono, K., Davies, S. J., \& Chua, Y. K. (2007). Performance of 45 native tree species on degraded lands in Singapore. Journal of Tropical Forest Science. 19(1), 25-34.

Slik, J. F., Keßler, P. J., \& van Welzen, P. C. (2015). Macaranga and Mallotus species (Euphorbiaceae) as indicators for disturbance in the mixed lowland Dipterocarp forest of East Kalimantan (Indonesia). Ecological Indicators, 2(4), 311-324.

Sumarhani. (2015). Aplikasi agroforestri sebagai upaya rehabilitasi Taman Wisata Alam Gunung Selok Cilacap yang terdegradasi. Prosiding Seminar Nasional Masyarakat Biodiversity Indonesia, 7(1) 1627-1632. doi://10.13057/psnmbi/m010715.

Suryanto, P., Zaki, M., Azani, M., \& Azmy, M. (2010). Species diversity of Gunung Merapi National Park, Java, Indonesia following 2006 eruption. Research in Environmental and Life Science, 3(1), 1-6.

Susilo, A. (2016). Uji coba penanaman lima jenis Dipterokarpa pada lahan bekas tambang di PT. Kitadin, Kalimantan Timur. Proceeding Biology Education Conference, 672-676. Surakarta: FKIP UNS.

Todd, A. J., Rufaut, C. G., Craw, D., \& Begbie, M. A. (2009). Indigenous plant species establishment during the rehabilitation of an opencast coal mine, South-East Otago, New Zealand. New Zealand Journal of Forest Science, 39, 81-98.

Turjaman, M., Santoso, E., Susanto, A., Gaman, S., Limin, S. H., Tamai, Y., ... Tawaraya, K. (2011). Ectomycorrhizal fungi promote the growth of Shorea balangeran in degraded peat swamp forests. Wetlands Ecology and Management. 19, 331-339. doi://10.1007/ s11273-011-9219-1.

Turner, E. A., Kroeger, G. L., Arnold, M. C., Thornton, B. L., Di Giulio, R. T., \& Meyer, J. N. (2013). Assessing different mechanisms of toxicity in mountaintop removal/valley fill coal mining-affected watershed samples 
using Caenorbabditis elegans. PLoS ONE. doi://10.1371/journal.pone.0075329.

Villacís, J., Casanoves, F., Hang, S., Keesstra, S., \& Armas, C. (2016). Selection of forest species for the rehabilitation of disturbed soils in oil fields in the Ecuadorian Amazon. Science of the Total Environment, 566, 761-770.

Widyawati, T., Purnawan, W. W., Atangwho, I. J., Yusoff, N. A., Ahmad, M., \& Asmawi, M. Z. (2015). Anti-diabetic activity of Sysygium polyanthum (Wight) leaf extract, the most commonly used herb among diabetic patients in Medan, North Sumatera, Indonesia. International Journal of Pharmacentical Sciences and Research, 6(4), 1698-1704.

Woodbury, D. J., Yassir, I., Arbainsyah, Doroski, D. A., Queenborough, S. A., \& Ashton, M. S. (2020). Filling a void: Analysis of early tropical soil and vegetative recovery under leguminous, post-coal mine reforestation plantations in East Kalimantan, Indonesia. Land Degradation and Development, 31(4), 473487. doi://10.1002/ldr.3464.

Wulandari, D., Saridi, Cheng, W., \& Tawaraya, K. (2016). Arbuscular mycorrhizal fungal inoculation improves Albizia saman and Paraserianthes falcataria growth in a postopencast coal mine field in East Kalimantan, Indonesia. Forest Ecology and Management, 376, 67-73. doi://10.1016/j.foreco.2016.06.008.

Yassir, I. (2013). Bersinergi dengan alam dalam reklamasi hutan bekas tambang batubara. Swara Samboja, 2(2)7-9.

Yassir, I. (2016). Diversity of Plant communities in secondary succession of imperata grassland in Samboja Lestari East Kalimantan, Indonesia. Indonesian Journal of Forestry Research, 1(2), 139-149.
Yassir, I., \& Mitikauji, Y. (2007). Pengaruh penyiapan lahan terhadap pertumbuhan Shorea leprosula Miq. dan Shorea balangeran (Korth.) Burck. pada lahan alang-alang di Samboja, Kalimantan Timur. Jurnal Penelitian Ekosistem Dipterokarpa, 1(1), 23-35.

Yassir, I., \& Omon, R. M. (2009). Pemilihan jenisjenis pohon potensial untuk mendukung kegiatan restorasi lahan tambang melalui pendekatan ekologis. Prosiding Workshop IPTEK Penyelamatan Hutan Melalui Rehabilitasi Lahan Pasca Tambang Batubara, 64-76. Samarinda: Balai Besar Penelitian Dipterokarpa.

Yassir, I., van der Kamp, J., \& Buurman, P. (2010). Secondary succession after fire in imperata grasslands of East Kalimantan, Indonesia. Agriculture, Ecosystems and Environment, 137(1-2), 172-182. doi://10.1016/j. agee.2010.02.001.

Yusuf, R., \& Purwaningsih. (2012). Keanekaragaman jenis tumbuhan hutan sekunder pada berbagai tingkatan umur di Kuala Ran, Kab. Bulungan-Kalimantan Timur. Jurnal Teknik Lingkungan, (Edisi Khusus "Hari Bumi"), 4152.

Zegre, N. P., Miller, A. J., Maxwell, A., \& Lamont, S. J. (2014). Multiscale analysis of hydrology in a mountain top mine-impacted watershed. Journal of the American Water Resources Association, 50(5), 1257-1272. 